\title{
Three new species of the genus Atomaria (Coleoptera: Cryptophagidae) from eastern Palaearctic
}

\section{Три новых вида рода Atomaria из восточной Палеарктики (Coleoptera: Cryptophagidae)}

\author{
G.Yu. Lyubarsky \\ Г.Ю. Аюбарский
}

Zoological Museum, Moscow Lomonosov State University, Bol’shaya Nikitskaya 6, Moscow,125009 Russia.

Зоологический музей, Московский государственный университет им. М.В. Ломоносова, Большая Никитская ул., 6, Москва 125009, Россия.

KEYWORDS. Coleoptera, Cryptophagidae, Atomaria, Siberia, Far East, new species.

КЛЮЧЕВЫЕ СЛОВА. Coleoptera, Cryptophagidae, Atomaria, Сибирь, Дальний Восток, новые виды.

ABSTRACT. Three new species of Cryptophagidae are described from Siberia and Far East: Atomaria kerzhneri sp.n., A. aleatoria sp.n., and $A$. acerba sp.n.

РЕЗЮМЕ. Описаны три новых вида рода Atomaria из Сибири и с Дальнего Востока: Atomaria kerzhneri sp.n., A. aleatoria sp.n., and A. acerba sp.n.

\section{Introduction}

The cryptophagid fauna of Palaearctic in currently known to contain 368 species [Johnson, 2007], including about 127 species of the genus Atomaria Stephens, 1829. 46 species belong to subgenus Anchicera Thomson, 1863 from Asia. Both adults and larvae are commonly found on mold, fungi, under bark as well as in decaying vegetation. Larvae are mycetophagous, generally feeding on fungal material, whatever the habitat, in decaying plant material, or in rotting wood, or in dried plant material.

The key to species of the Far East is currently outdated [Lyubarsky, 1992], and therefore I provide a new key for distinguishing between some species of the genus Atomaria.

This work is based on material from Zoological Museum of Moscow State University (ZMMU). All materials, including types, have been deposited in this museum.

\section{Taxonomy}

Atomaria (Anchicera) kerzhneri sp.n. Figs 1-2

TYPE MATERIAL: Holotypus $\sigma^{7}$ : Tretyjakovo, Kunasiri Island, 03.08.1973, leg. Kerzhner I.M.

Paratypes: Far East: Ussurijsk distr., Kamenushka village, 28.06.1984, leg. G.Yu. Luybarsky ( $($ ); the same data, 28.06.1984, leg. Nikitsky N.B. $\left(2+, 10^{7}\right)$; the same data, 06.07.1980, leg. Nikitsky N.B., Belov V.V. $\left(\mathrm{O}^{7}\right)$.
DESCRIPTION. Length of body 1.4-1.6 mm, elongate (Fig. 1), moderately arched, covered with slightly curved but decumbent pale pubescence of moderate length.

Body entirely light brown, yellowish or reddish-brown.

Antennal structure as in Fig. 1, segments $1^{\text {st }}, 3^{\text {th }}, 5^{\text {th }}$ about 1.5 times as long as broad, segment $7^{\text {th }}$ about $1.0-1.3$ times as long as broad, segment $9^{\text {th }}$ slightly transversal, and $10^{\text {th }}$ strongly transversal.

Pronotum distinctly transverse, broadest at or just behind the middle where it is 1.3-1.4 times as broad as long. Side borders only visible from above in the basal third; moderately strongly and moderately densely punctured, punctures separated by 0.5 diameters apart from their lateral neighbours; base of the pronotum without depression or sligthly defined depression in the middle; hind angles obtuse; pronotal disk convex; hind margin finely bordered.

Elytra long oval, moderately arched, weakly curved at sides, broadest approx. at first third of length, 2.0-2.3 times as long as pronotum, 1.2-1.4 times as long as broad combined. Surface shining, moderately closely punctured, the punctures in the basal part slightly smaller than those on the pronotal disk, and approximately 1.0-1.5 diameters apart from their lateral neighbours on an average; elytral humeri not toothed. Hind wings fully developed.

Male genitalia as in Fig. 2. Paramere plate with long hair.

ETYMOLOGY. Named in honour of Russian entomologist Izyaslav Moiseyevich Kerzhner (1936-2008).

REMARKS. A. kerzhneri sp.n. is similar to Atomaria testacea (Stephens, 1830) (Figs 3-4). A. kerzhneri sp.n. has more dense punctation of pronotum, stronger punctation of elytra, a lighter colour, less transverse club of antenna, more transverse pronotum.

A. kerzhneri sp.n. belongs to the Anchicera group of species, characterized by prothorax dilating towards base.

Key to SPECIES OF ATOMARIA (ANCHICERA) FROM NORTH Asia. The GROUP OF SPECIES WITH PROTHORAX DILATING TOWARDS BASE.

1. Segments of flagellum very long and thin, $1^{\text {st }}$ segment noticeably longer than wide, $3^{\text {th }}, 5^{\text {th }}$, and $7^{\text {th }} 2.0-2.5$ times as long as wide ........................................................... 2

- Segment of flagellum not as long and thin, $5^{\text {th }}$ less then 2 times as long as wide ................................................. 5 
2. Pronotum with longitudinal folds at the base A.plicata

- Pronotum without longitudinal folds at the base ........ 3

3. Pronotum widest near posterior angles, evenly narrowed to apex. $1^{\text {st }}$ antennal segment less than 1.5 times as long as wide. Base of pronotum strongly punctate. Punctation of elytra very slight. Pubescence of elytra short

A. kaszabi

- Pronotum equally wide at the base and mid-length, lateral margin near the middle of its length forming an angular contour. Punctation of base of pronotum and elytra less different. Punctation of elytra stronger ....................... 4

4. $1^{\text {st }}$ antennal segment more than 1.5 times as long as wide Pronotum flattened, with broad transverse depression. Beetle often bicolored, pronotum black, elytra darkened basally, disc of elytra red ........................ A.plicatoides

- $1^{\text {st }}$ antennal segment short, less than 1.5 times as long as wide. Pronotum convex, with narrow transverse depression. Beetle usually unicolor, dark-brown or reddish ...

A. fulvipennis

5. Segments of flagellum short, thick. Width of $1^{\text {st }}$ antennal segment more than half of width of eye, segments of flagellum slightly thinner than $1^{\text {st }}$ antennal segment. Antennal club rather slender, $9^{\text {th }}$ segment slightly transversal. $1^{\text {st }}$ antennal segment long, more than 1.5 times as long as wide and longer than $2^{\text {th }}$ antennal segment. Parameral plate on top broadly rounded ........................ A.turgida

- Segments of flagellum slender ...................................... 6

6. Either $1^{\text {st }}$ or $5^{\text {th }}$ antennal joint much elongated ........... 7

- Both $1^{\text {st }}$ and $5^{\text {th }}$ antennal segments short .................... 10

7. $1^{\text {st }}$ antennal segment short, less than 1.5 times as long as wide; $5^{\text {th }}$ segment long, more than 1.5 times as long as wide. Club of antenna slender, its segments not trans-

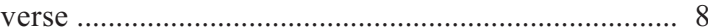

- $1^{\text {st }}$ antennal segment long, more than 1.5 times as long as wide and longer than 2 th segment. $5^{\text {th }}$ segment short, not more than 1.5 times as long as wide. Club of antenna broad, its segments transverse ...................... A.apicalis

8. Pubescence outstanding ............................... A.graeseri

- Pubescence accumbent ................................................. 9

9. Bicolored, pronotum much darker than elytra, dark brown, or entirely one-colored ligth.................... A.fulvipennis

- Unicolor, dark, pronotum and elytra black or dark brown. Sometimes apex of elytra and shoulders slightly lighter A.nitidula

10. Plate of paramere with cutting at the apex ....... A.lederi

- Plate of paramere without cutting at the apex ........... 11

11. Dark, often black or dark brown. Plate of paramere without hairs at the apex. Club of antenna broad, $9^{\text {th }}$ antennal segment transversal. Pronotum almost not dilated at the base, of equal width from mid-length to base, pronotum weakly transverse, about 1.2-1.4 times wider than long. Punctation of elytra sparse and weak, diameter of point much smaller than that of points on pronotum, distance between points about 2 diameters of point. Length of body $1.3-1.6 \mathrm{~mm}$..................................... A.testacea

- Light, usually red or stramineous. Plate of paramere with hairs at the apex. Club of antenna slender, $9^{\text {th }}$ antennal segment slightly transversal. Pronotum dilating towards base and widest at base; pronotum strongly transverse, about 1.3-1.4 times wider than long. Punctation of elytra strong and dense, diameter of point almost equal to that of points on pronotum, distance between points less than 1 diameter of points. Length of body 1.4-1.6 mm

\section{Atomaria (Atomaria) aleatoria sp.n. Figs 5-6}

MATERIAL. Holotypus $\sigma^{7}$ : Zeya State Reserve, $34 \mathrm{~km}$, 27.06.1978, leg. S. Kurbatov.

Paratypes: Russia: Zeya State Reserve, $52 \mathrm{~km}, 3.07 .1978$, leg. V. Belov; Zeya State Reserve, 52 km, 4.07.1978, hay, leg. S. Kurbatov; S Kunashir, Tretyakovo, 21.07.1985, leg. A. Makarov; Amur Area, Zea, ultraviolet, 26.07.1978, leg. S. Kurbatov; S Ural, 500 m, 90 km W Sibay, nr. Beryozovka, 16-24.07.2000, leg. S. Kurbatov; Khanty-Mansyisk Autonomous Region, Surgut District, Yugansk State Reserve., Ai-Magromsy River Basin, Medvezhiy Ugol, in wood and land lamellar mushrooms, 16.09.2002, leg. A.B. Ryvkin

DESCRIPTION. Length 1.7-2.1 mm, elongate (Fig. 5), moderately arched, covered with slightly curved but decumbent pale pubescence of moderate length.

Head and prothorax dark brown or blackish, elytra reddish brown; antennae and legs reddish-brown.

Antennal structure as in Fig. 5, segment 1 ca. 2 times as long as broad, segments 9 and 10 strongly transverse.

Pronotum distinctly transverse, broadest at or just behind the middle where it is 1.3-1.4 times as broad as long, thence contracted the base where it is narrower than the base of the elytra; side borders only visible from above in the basal third; surface strongly and coarsely shagreened over the whole surface, moderately strongly and moderately densely punctured, punctures separated by $0.5-1.0$ diameters apart from their lateral neighbours; base of the pronotum with a narrow and well-defined depression in the middle; hind angles obtuse; pronotal disk convex; hind margin finely bordered.

Elytra long oval, moderately arched, weakly curved at the sides, broadest near in middle, 2.5-2.7 times as long as the pronotum, 1.4-1.5 times as long as together broad. Surface shining, strongly shagreened, rather closely punctured, the punctures in the basal part slightly smaller than those on the pronotal disk, and approximately 1-1.5 diameters apart from their lateral neighbours on an average; elytral humeri toothed or not. Hind wings fully developed.

Male genitalia as in Fig. 6.

REMARKS. This species differs from nearest species with transversal club of antennae and elongated $1^{\text {st }}$ segment of antennae (similar with A. elongatula Erichson, 1846, A. abietina J.R.Sahlberg, 1888 , but $A$. aleatoria sp.n. has a long $1^{\text {st }}$ segment of antennae); similar with $A$. vespertina Maklin, 1853, but $A$. aleatoria sp.n. has a transversal club, strongly rounded sides of pronotum, and strongly cutting aedeagus.

\section{Atomaria (Atomaria) acerba sp.n.}

Figs 7-8

TYPE MATERIAL. Holotypus $0^{7}$ : Sikhote-Alin Mts., Tardoki Mt., fir grove, $1400 \mathrm{~m}, 01.07 .1980$, leg. G. Lafer.

Paratypes: Russia: Amur Area, Zeya, ultraviolet, 11.06.1978, leg. S. Kurbatov (2 spec.); Amur Area, near Zeya, Sosnovyi Bor, 02.06.1978, leg. V. Belov, S. Kurbatov; Amur Area, Zeya State Reserve, 34 km, 27.06.1978, V. Belov; Evreyskaya Autonomous Region, Amur River, near Radde, Dichun, $130^{\circ}$ 45'E, 08.08.1978, leg. S. Kurbatov; Ussuriysk District, Kamenushka, 11.06.1984, leg. N.B. Nikitsky; Kamenushka, 12.05.1984, leg. N.B. Nikitsky (2 spec.); Kamenushka, 04.06.1984, leg. N.B. Nikitsky; Evreyskaya Autonomous Region, Amur River, near Radde, Dichun, $130^{\circ} 45^{\prime} \mathrm{E}$, 18.08.1978, leg. V. Belov, S. Kurbatov; Transbaikalia, Vitim River, Ust'-Zaza, 5-6.06.1969, leg. A.P. Rasnytsin; Krasnoyarsk Province, Ermakovo District, Verkhneusinsk, 25.05.-04.06.1989, leg. A.B. Ryvkin (3 spec.); Krasnoyarsk Province, Sayano-Shushensky State Reserve, Shugur, litter under stones near poplars and cereals, near brook, 21.05.1989, leg. A.B. Ryvkin (2 spec.); Khanty-Mansyisk Autonomous Region, Surgut District, Yugansk State Reserve, 
Ai-Magromsy River Basin, Medvezhiy Ugol, litter under stones, moss near Pinus, Abies, Butula with Vaccinium vitis-idaea, V.myrtillus, Pleurozium schreberi, Hylocomium splendens, Dicranum polysetum, Sphagnum ?warnstortii, Linniaea borealis, Equisetum sylvaticum and other, 18.09.2002, leg. A.B. Ryvkin.
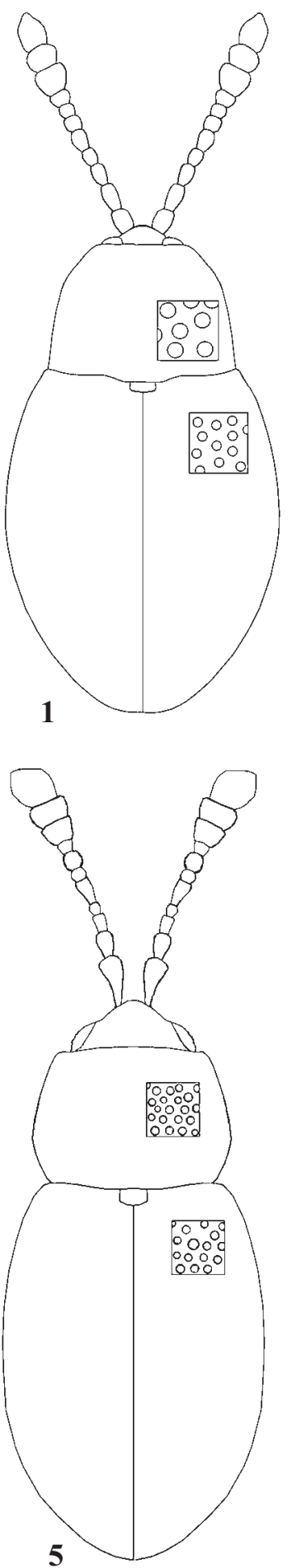

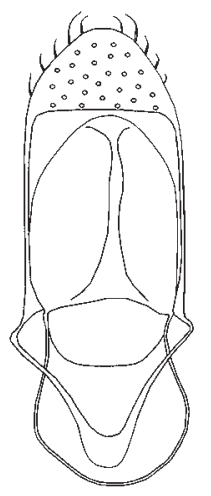

2

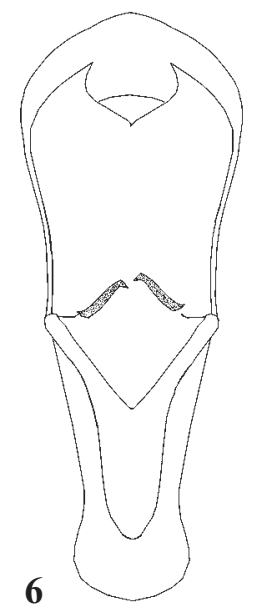

DESCRIPTION. Length 1.6-1.9 mm, elongate (Fig. 7), moderately arched, covered with slightly curved but decumbent pale pubescence of moderate length.

Head and prothorax dark brown or blackish, elytra reddish brown; antennae and legs reddish-brown.

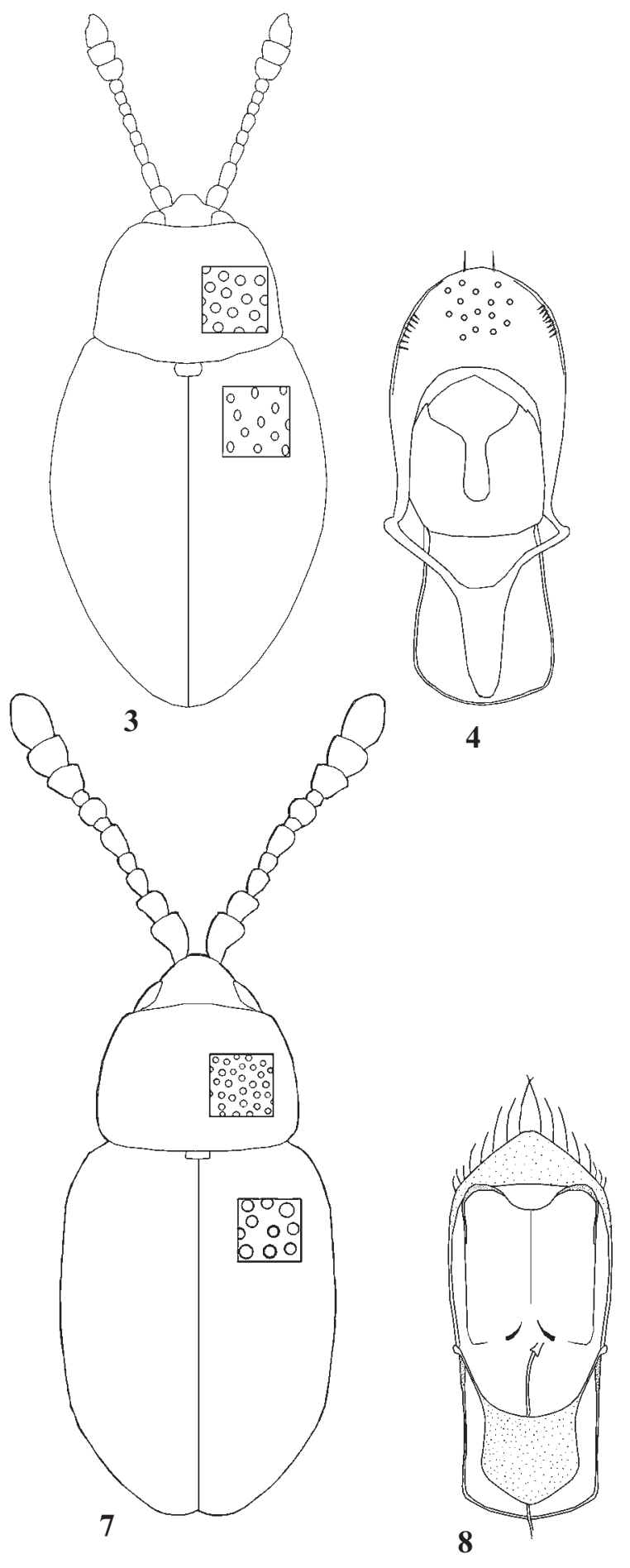

Figs 1-8. Atomaria spp: 1-2 - A. kerzhneri sp.n.; 3-4 - A. testacea; 5-6-A. aleatoria sp.n.; 7-8 - A. acerba sp.n.; 1, 3, 5, 7habitus; 2, 4, 6, 8 - male genitalia.

Рис. 1-8. Atomaria spp: 1-2 - A. kerzhneri sp.n.; 3-4-A. testacea; 5-6 - A. aleatoria sp.n.; 7-8 - A. acerba sp.n.; 1, 3, 5, 7 общий вид; 2, 4, 6, 8 - гениталии самца. 
Antennal structure as in Fig. 4, segment 1 is 1.6-2.0 times as long as broad, segments 9 and 10 weakly transverse.

Pronotum 1.3-1.4 times as broad as long, distinctly transverse, broadest behind the middle, then contracted to the base where being narrower than the base of the elytra; side borders only visible from above in the basal third; surface strongly and coarsely shagreened over the whole surface, moderately strongly and moderately densely punctured, punctures separated by 0.5 diameters apart from their lateral neighbours; base of the pronotum with a narrow and weakly depression in the middle; hind angles obtuse; pronotal disk convex; hind margin finely bordered.

Elytra long oval, moderately arched, weakly curved at the sides, broadest near in middle, 2.3-2.6 times as long as the pronotum, 1.5-1.7 times as long as together broad. Surface shining, strongly shagreened, rather closely punctured, the punctures in the basal part slightly smaller than those on the pronotal disk, and approximately $1-1.5$ diameters apart from their lateral neighbours on an average; elytral humeri toothed or not. Hind wings fully developed.

Male genitalia as in Fig. 8.

REMARKS. This species differs from nearest species with decumbent pubescence, weakly transversal club of an- tennae and short $1^{\text {st }}$ segment of antennae. A. gracilicornis Reitter, 1888 and A. wollastoni Sharp, 1867 differ from A. acerba sp.n. in the following characters: elongated $1^{\text {st }}$ segment of antennae, very narrow $9^{\text {th }}$ segment of antennae, and weakly transverse pronotum. A. acerba sp.n. differs from $A$. vespertina in the following characters: short $1^{\text {st }}$ segment of antennae, weakly transverse $9^{\text {th }}$ segment of antennae (sometimes club of antennae more transverse), distinctly transverse of pronotum, and genital characters. A. acerba sp.n. differs from A. gracilicornis, and A. edithae Reitter, 1888 in the following characters: rounded hind angles of pronotum, and unicolorous red colour (its differs from $A$. edithae in outstanding pubescence).

\section{References}

Johnson C. 2007. Cryptophagidae // I. Löbl \& A. Smetana (eds.). Catalogue of Palaearctic Coleoptera. Vol. 4. Elateroidea, Derodontoidea, Bostrichoidea, Lymexyloidea, Cleroidea, Cucujoidea. Apollo Books. P.514-531.

Lyubarsky G.Yu. 1992. [Family Cryptophagidae] // Opredelitel' nasekomykh Dal'nego Vostoka SSSR. Vol.3. No.2. St-Petersburg: Nauka. P.245-274 [in Russian]. 